\title{
改良型免疫アルゴリズムによる 構造設計支援に関する研究
}

\section{中村 秀明*1 宮本 文穗*1 松本 剛*2}

\begin{abstract}
近年，遺伝的アルゴリズム (GA：Genetic Algorithm)が組合せ最適化問題をはじめとする種々の最適化問 題へ盛んに適肘されている，GAは多点探索と交取オペレータにより最適解を得るため, 状態空間を広く探索 することが叮能である。しかしながら，GAでは，解の探索が不十分な時点で集団の多様性が急速に失われる ことがある。この䦓題を解決するため，集団の多様性維持を目的とした手法がいくつか提案されている.

免疫アルゴリズム(IA：Immune Algorithm) は, 生体のもつ免疫システムを模倣した最適化手法であり, 解 の多様性を維持するとともに, 複数の準最適解を得ることが可能である. 本研究では, 鼠適設計問題に, この IA を適用することを念頭に，IA の改良を行い，より確奞に複数の多様性を持った解が探索できるようにし た。さらに改良を行ったIA を耐衝撃設計問題に適用し，最適設部問題に対するIAの有效性を示した。 キーワード：免疫アルゴリズム $(\mathrm{IA})$ ，遺伝的アルゴリズム $(\mathrm{GA})$ ，最適設計，多样性
\end{abstract}

\section{1.はじめに}

組合せ最適化問題では，考慮すべき組合せ数が，問 題の規模に応じて指数関数的に增大するため，実用的 な最適解が現実的な時間内に得られない場命が多い。 特に，丁学分野に扔ける最適設計問題などでは，考虑 すべき設計パラメーターが多数あるため，その組合せ 数は，膨大な数となることが予想される。近年，この ような組合せ最適化問題の解法として遺伝的アルゴリ ズム(GA : genetic algorithm)[1][2]が盛んに用いら れている.GA は, 生物の遺伝と進化のメカニズムを工. 学的にモデル化したものであり，生物の進化過程にお ける遺伝的操作，すなわち，個体の遺伝子の選択，交 义，突然変異を模倣した最適化·探索手法である，GA では, 複数の探卖点が相互協力的に解を探索していく ため，比較的短時間で準最適解を得ることが可能であ り，各個体の遺伝子情報と適応度のみがわかれば解の 探荣を行うことができることから，目的関数が微分不 可能な評価関数である問題にも適用でき，GA を用い た設計支援システム[3]など，多くのGA を適用した 研究がなされている.

しかしながら GAでは，解の探素が不十分な時点 で，集団の多様性が袈失する現象がしばしば生じる。

+ Application of the Improved Immune Algorithm to a Structural Design Support System

Hideaki NAKAMURA, Ayaho MIYAMOTO and Tsuyoshi MATSUMOTO

*1 山日大学工学部知能情報システム厂学科

Department of Computer Science and Systems Engineer. ing, Faculty of Engineering, Yamaguchi University

*2 晒日本電信電話株式会社 (NTT 西目本)

Nippon Telegraph and Telephone West Corporation (NTT WEST)
この現象は，一般に初期收束と呼ばれ，探索の初期段 階で他の解に比べ優れた解が生成された場合，その解 が集団中に多数残り，同一の遺伝子型の個体との間で 交叉が行われやすくなり，解集闷の多様性が急速に失 われる現象である。この問題を解決するため，集団の 罗様性維持を目的とした手法がいくつか提案されてい る $[4][5][6][7]$.

一方，工学分野における通常の最適設計問題では， 非常に幅広い設計空間の中から，最適な解を見つける 必要があり，環境条件や製作や施工の手間など，目的 関数の中に含めることのできない要因が多数存在する。 このような場合に，異なる特徵をもつた複数の最適設 計案が提示されれば，設計者は，その案をもとに設計 を行うことが可能となる。このような問題に対しては, 概社1つの準最適解しか得られないGA では不十分で あると考えられる。

GA とは異なる最適化手法として, 生体のもつ免疫 システム $[8][9][10]$ に基づいた最適化手法がいくつか 提案されている。森ら[11]は，免疫システムに基づい た新しい最適化手法として免疫アルゴリズム (IA： Immune Algorithm) を提案している。このIA は, GA の sharing 法に似た方法で初期収束を避けており，解 の多様性を維持するとともに, 複数の準最適解を得る ことが可能である。

本研究では, 最適構造設計問題にIA を適用するこ とを念頭に，IAの改良を行い，より確実に複数の多様 性を持った解が探索できるようにした。ささらに，構造 設計支援への適用例として, 衝撃荷重を受ける鉄筋コ ンクリート (RC) 版の設計問題を取り上げ, 耐衝撃性に 優れた RC 版の設計支援システムの構築を行った。 


\section{2. 改良型免疫アルゴリズム}

(Improved Immune Algorithm)

\section{1 改良型免疫アルゴリズムの概要}

免疫アルゴリズム (IA)は, 生体の持つ免疫システム の抗体産生機構とその自己調節機構を工学的にモデル 化した最適化アルゴリズムである。免疫には，生体を 抗原から守るために免投細胞が自己と非自己(抗原)を 識別する機能と, 非自己である病原菌やウィルス, あ るいは病気等のために変化した自己成分を排除する機 能が備わっている。生体の免投システムは生体内に侵 入してくる抗原に対して, 細胞遺伝子の再構成を行う ことによりその抗原に対応する抗体を産生し，産生さ れた抗体を増殖することにより抗原の排除を行う。中 でも替椎動物における先疫機構は，過去に排除したこ とのある抗原に対して有効であった抗体を記憶細胞に 記憶しており，再び出現した抗原に対して直接有効な 抗体をつくる機能を持っている。また，免疫システム は自己に対しても免疫性を示すことが知られている。 同一種類の抗体が大量に産生されたとき，抗体産生を 抑制する機能を持つサプレッサ一細胞によりその抗体 と闰種類の抗体の産生を抑制し，バランスの崩れた状 態から定常状態に戻そうとする機構を有している。本 研究では, 多様性を維持し，より確実に複数の準最適 解が得られるように従来のIA[11]の一部を改良して 適用した。本研究で用いた改良型IAの基本的なアル ゴリズムの概要を図-1に示す。

\section{【Step1】抗原の認識}

抗原をシステムに認識させる。最適化問題において 抗原は目的関数と制約条件にあたる。したがって，目 的関数および制約条件をシステムに組み込み，それら

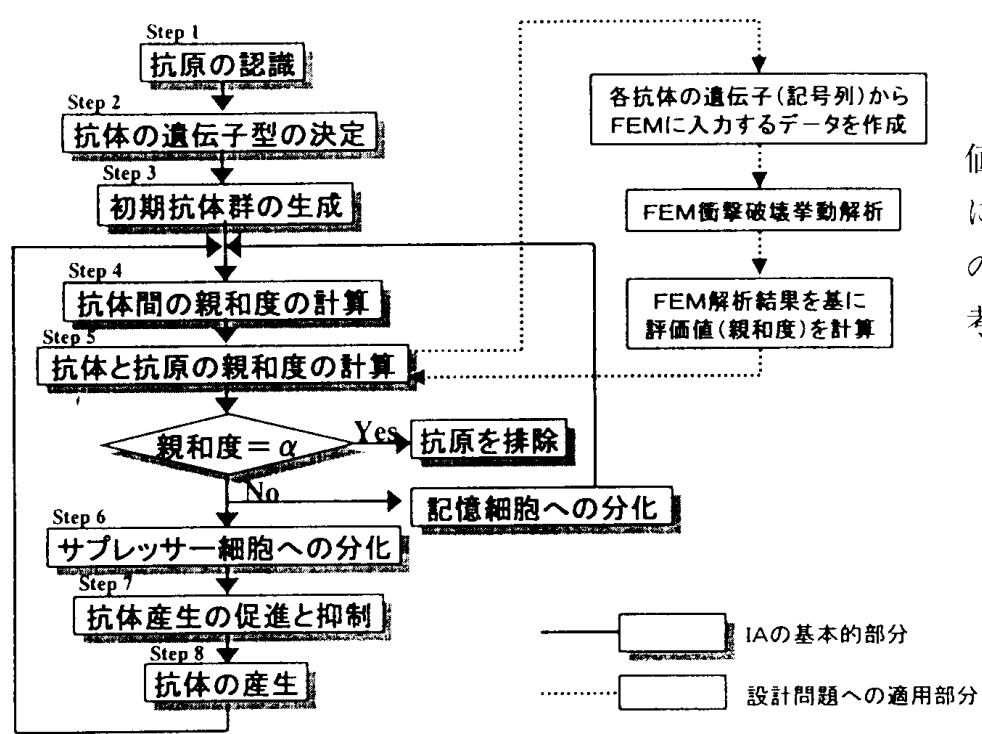

図-1 改良型免投アルゴリズムの概要
を制御するパラメータがあれば入力情報として与える ことにより抗原を認識させる。

\section{【Step2】抗体の遺伝子型の決定 (Coding)}

対象とする問題の事象にあたる抗体の遺伝子要素を 記号列で表すことにより，対象とする問題にIAを適 用することができる。つまり，IAに適用するには，対 象とする問題の入力デー夕を記号列 (抗体)八変換する 必要がある。通常, 各抗体は1次元配列の遺伝子型であ

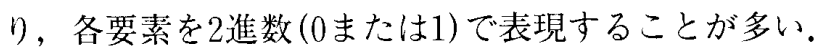

\section{【Step3】初期抗体群の生成}

Step2で決められたモデルに基づいて，記号列を多 数発生させる。このとき，記憶細胞により過去に有効 であった抗体群を生成する。つまり，過去に有效であ った抗体 (解候補)を保存した記憶細胞 (データべース) から抗体を読み込み，初期抗体群を形成する。その概 念を四一2に亦す。記憶細胞が存在しないとき，あるい は初期抗体数に満なないときには，抗体の各遺伝子を ランダムに決定し，遺伝子が異なる抗体を発生させる ことにより，初期抗体群を生成する。

\section{【Step4】抗体間の親和度の計算}

全抗体について他の全ての抗体との親和度 (類似性) を測定する。抗体と抗体との親和度 $a y_{i, j}$ は次式により 得られる。

$$
a y_{i, j}=1 /\left(1+H_{i, j}\right)
$$

ここで， $H_{i, j}$ は抗体 $i$ と抗体 $j$ との距離であり, $H_{i, j}=0$ のとき, 㧤体 $i$ と抗体 $j$ は完全に一致.一般には 八ミング距離が用いられる。

\section{【Step5】抗原と抗体間の親和度の計算}

全抗体について抗原との親和度 (解の評価值)を計算 する. 抗原と抗体間の親和度 $a x_{i}$ は次式により得られ る.

$$
a x_{i}=o p t_{i} \quad\left(0 \leqq o t p_{i} \leqq \alpha\right)
$$

ここで，opt $t_{i}$ は抗原と抗体 $i$ との結合力の強さの評価 使であり，0から $\alpha$ で規格化し， $\alpha$ が最適解になるよう に定義する．つまり，親和度 $a x_{i}$ の值が $\alpha$ のとき抗原 の排除に成功した(これ以上最適な解は存在しない)と 考える。

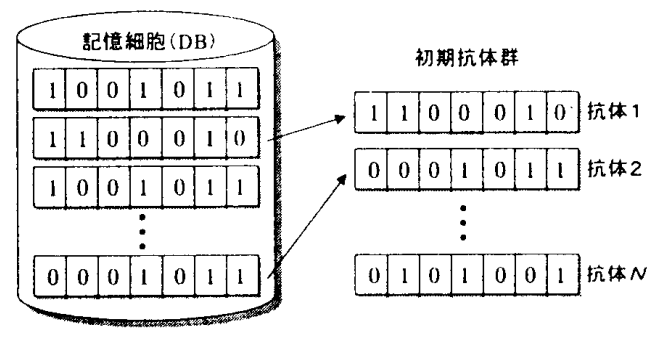

図-2 記憶細胞が存在したときの初期抗体群の生成 


\section{【Step6】記憶細胞とサプレッサー細胞への分化}

探索過程で得られた有効な抗体を記憶細胞とサプレ ッサー細胞として産生する。ここで産生される記憶細 胞が最適解の候補となる。

まず, 全ての抗体の濃度を計算し, 抗体の濃度 $c_{i}$ が 閾値 $\left(T_{c}\right)$ を超えた抗体 $i$ を記憶細胞に分化させる。た だし, 全ての記憶細胞とその抗体の親和度を計算し, 記憶細胞との親和度があらかじめ決めておいた闌值 $\left(T_{a c 3}\right)$ を越えた場合には，その記憶細胞との入れ換え を行う。また，記憶細胞の数には限りがあり，記憶細 胞の総数が上限に達したときは，それまでに保存じて きた記憶細胞と分化した記憶細胞との親和度を計算し， その中で最も親和度の高い記憶細胞と入れ換えを行う。 ここでは，抗原との親和度が選択した記憶細胞よりも 分化した記憶細胞の方が高い場合のみ入れ換えを行う。

次に，新しく分化した記憶細胞と同じ遺伝子型を持 つ抗体をサプレッサー細胞に分化させる。ただし，同 世代に分化する記憶細胞は1つ以下とし，候補の中で最 も期待值の大きい抗体とする。

抗体 $i$ の濃度 $c_{i}$ は次式で与えられる。

$$
\begin{gathered}
c_{i}=\frac{\sum_{j=1}^{N} a c_{i, j}}{N} \quad\left(0 \leqq c_{i} \leqq 1\right) \\
a c_{i, j}= \begin{cases}1 & \text { ayi,j } \\
0 & \text { otherwise }\end{cases}
\end{gathered}
$$

ここで， $T_{a c 1}$ は類似度の閾值であり，Nは抗体の総 数である。つまり, 抗体 $i$ と抗体 $j$ がある程度の類似性 $\left(T_{a c 1}\right)$ を持っているとき, 同一種類の抗体とみなする とを示している。

\section{【Step7】抗体産生の促進と抑制}

(1) 抗体の中で抗原との親和度の低いものから $N / 2$ 個 を自然消滅させる。

(2) (1)の操作で生き残った各抗体についてサプレッ サー紐胞との親和度を計算し, 親和度が閾値を超え た抗体を消滅させる。この操作により同じ記憶細胞 の産生を回避することができる。

(3) 抗体の次世代に残る期待値を次式により与える.

$$
\begin{gathered}
e_{i}=\frac{a x_{i} \prod_{s=1}^{S}\left(1-a s_{i, s}^{k}\right)}{c_{i} \sum_{j=1}^{N^{\prime}} a x_{j}} \\
a s_{i, s}= \begin{cases}a y_{i, s} & a y_{i, s} \geq T_{a c 2} \\
0 & \text { otherwise }\end{cases}
\end{gathered}
$$

ここで， $T_{a c 2}$ は類似度の閾値であり， $N^{\prime}$ は生き残っ ている抗体数, $S$ はサプレッサ一細胞の総数, $k$ は産生 抑制力 (Suppress power)である。
式 (5)により期待值を与えることで,抗原との親和度 が高い抗体ほど次世代に残る確率を高く，そしてサプ レッサー細胞との親和度が高く濃度が高い抗体ほど次 世代に残る確率を低くする。サプレッサ一細胞に反応 する抗体の産生を抑制することにより，同種類の記憶

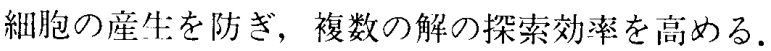

\section{【Step8】抗体の産生}

(1) Step7-(2)で消滅した抗体に代わる抗体を産生す る. 乱数を朋いて各遺伝子をランダムに決定すること により抗体を産生する。 (2)次にStep7で残った抗体と 新しく産生した抗体に対して, 重複を許して $N / 4$ 組の 抗体のペアを選択する。ここで, 確摔的に期待值が高 い抗体ほど選択されやすいものとする。ペアになった 抗体に対して交刃を行い, 新しく $N / 2$ 個の抗体を産生 する，産生した抗体に対して突然変晎操作を行い，遺 伝子を変化させる。ただし，交义方法と㔖然変異確率 は任意に設定する。ここで, 交叉と突然変異にはGA [1]で行う交叉と突然变異と间じ操作を晸いる。

Step4からStep8までをあらかじめ設定していた最 終慍代に達するまで行う。

\section{2 従来の免疫アルゴリズムからの变更点}

従来のアルゴリズムでは, Step7において全抗体に 対してサプレッサー細胞により抑制を行った後に，親 和度が低い $N / 2$ 個の抗体を自然消滅させていた。しか し，すでに得られている解候補の産生を防ぐには，全 抗体からではなく, 親和度の高い抗体の中から京一種 類の抗体を消隇するだけで效果があると思われるため, 本アルゴリズムでは，全抗体の中で親和度の低い $N / 2$ 個の抗体を消滅した後にサプレッサー細胞による抑制 を行う手順に変更した。図一3にその過程の抗体数の推 移を示す。このアルゴリズムの変更により，サプレッ サー細胞により消滅される抗体の数が少なくなるため, 交义を行う際に同種類の抗体を産生する可能性が高く なると思われる。つまり，サプレッサー細胞の抑制効 果を適度に残しつつ，抗体は従来のIA と比較すると 収束しやすく, 記憶細胞を1つ産生するまでの世代数は 小さくなることが期待でき，その分，一定世代数の中 でより多種類の記憶細胞を産生することが期待される。

また，確害に抗原との親和度の高い抗体を記憶細胞 (解候補)として残していくため，Step6に扔ける毁憶 細胞の産生時に2つの条件を付尗した．1つは記憶細胞 の入れ換えを行うときに，単に一定の濃度を超えた抗 体を記憶細胞と入れ換えてしまうと，その抗体よりも 条件に合った記憶細胞を消滅させてしまう可能性があ り，それを防ぐために記憶細胞と抗体のうち抗原との 親和度が高い方を記憶細胞として生存させる条件であ 


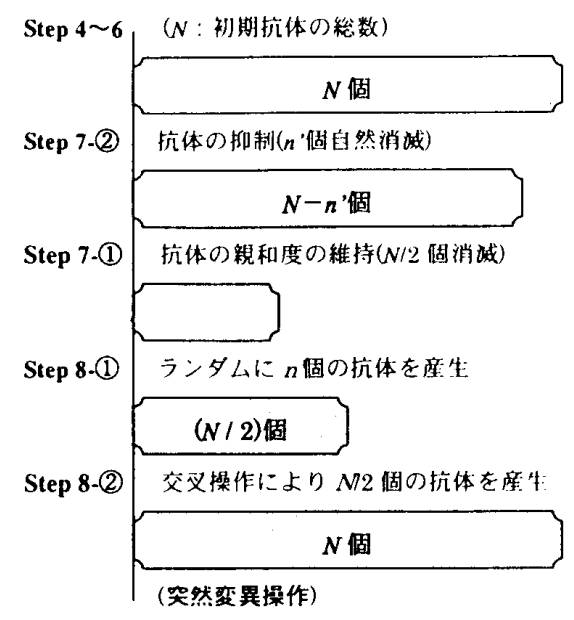

(1)徉来の। A

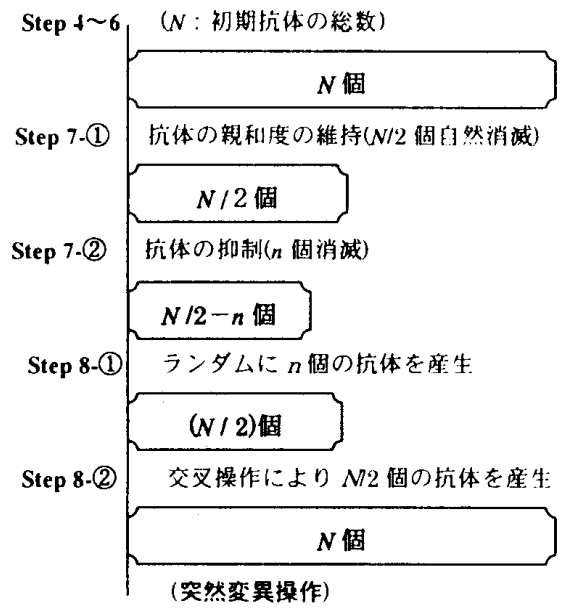

(2)改良型 IA

図-3 抗体数の推移

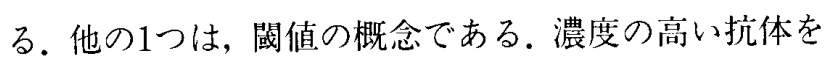
記憶細胞に分化させる際に，それまでに産生された記 憶細胞との親和度があらかじめ決めておいた間值より も大きい場合，その抗体は記憶細胞と同一種類の細胞 とみなし，記憶細胞との入れ換えを行う。これらの条 件が存在しない場合，記憶細胞容量が小さいときに全 ての記憶細胞が同傾向にある(記憶細胞間の距離が短 い) 結果に陷る可能性があり, 多様性を持った解候補群 を形成することが困難になる。

\section{3. 改良型免疫アルゴリズムの検証}

改良型 IA の特徵の理解を容易にするため, その比 較対象として, 単純 GA および従来の IA を取り上げ, 次式で定義される多峰性関数 $F 1(x), F 2(x)$ を対象と したシミュレーションを行った。

$$
\begin{aligned}
F 1(x)= & \sin ^{6}(5 \pi x) \\
F 2(x)= & \exp \left[-2 \log (2)\{(x-0.1) / 0.8\}^{2}\right] \\
& \sin ^{6}(5 \pi x)
\end{aligned}
$$

ここで, 関数 $F 1(x)$ は高さが等しい5つのピークを もつ関数であり, 関数 $F 2(x)$ は高さが異なる 5 つの ピークをもつ関数である.

シミュレーションの条件としては, 関数 $F 1(x)$,

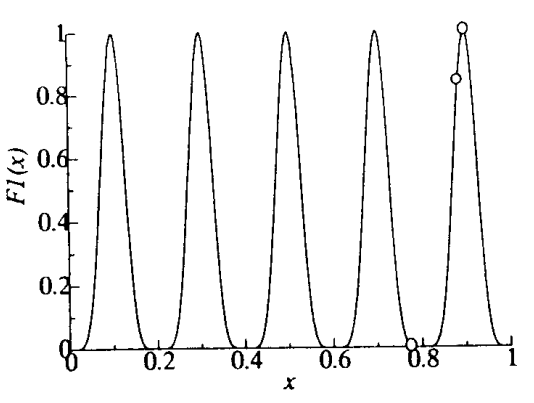

(a)単純 GAによって進化した個体
$F 2(x)$ に対する両シミュレーションにおいて，一つの

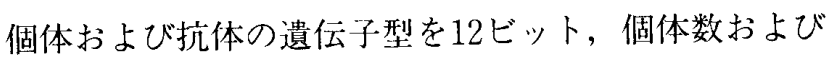
抗体数 30 , 交叉確率 1.0 , 突然変異確率 0.01 , 交叉操作 には一点交叉, 乫然変異操作には任意しビットの反転を 用いたＩA では，各閾値を $T_{a c 1}=0.50 ， T_{a c 2}=0.50$ ， $T_{a c 3}=0.50$ とし,サプレスパワーを 1.5 , 記憶細胞(解候 補) 容量を20抗体とした。 また, 関数 $F 1(x)$ に対するシ ミュレーションでは $T_{c}=0.5$, 世代数 200 とし, 関数 $F 2(x)$ に対するシミュレーションでは $T_{c}=0.6$, 世代 数100 と設定した。関数 $F 1(x)$ および関数 $F 2(x)$ に対 するシミュレーションの結果をそれぞれ図-4と図-5に 示す。な抢，ここでは $x$ に対する関数の值が大きなも のほど良好な解と設定する。

四-4(a)および図-5(a)に示す図中の“○”マーク は, それぞれ関数 $F 1(x), F 2(x)$ に対して単純 GAに よって最終世代までに進化した個体の適応度をプロッ トしたものであり，図-4(b)および図-5(b)に示方図中 の “○”マークは，それぞれ関数 $F 1(x), F 2(x)$ に対 して従来のIAによって最終世代までに得られた記憶 細胞の親和度をプロットしたものである。

図-4 (a) に示すように, 関数 $F 1(x)$ は $5 つ の$ 最適解を 有する関数であるにも関わらず，単純 GA では大部分

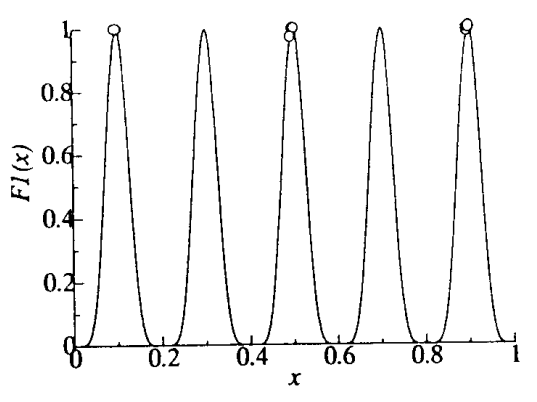

(b)従来のIAによって得られた記檍紐胞

図-4 関数 $F 1(x)$ に対するシミュレーション結果 


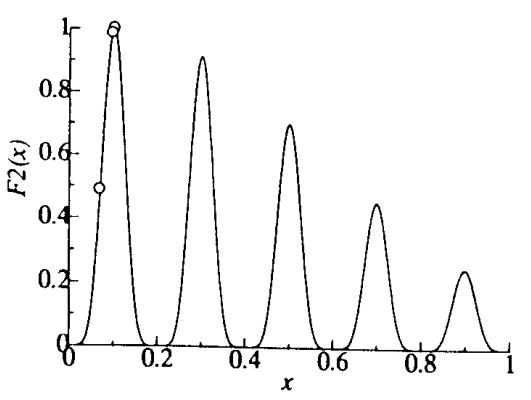

(a)単蚛 GAによって進化した個体

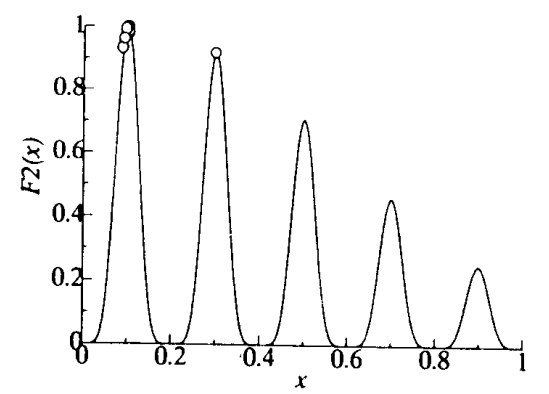

(b)従来のIAによって得られた記㙁細胞

图-5 関数 $F 2(x)$ に対するシミュレーション結果

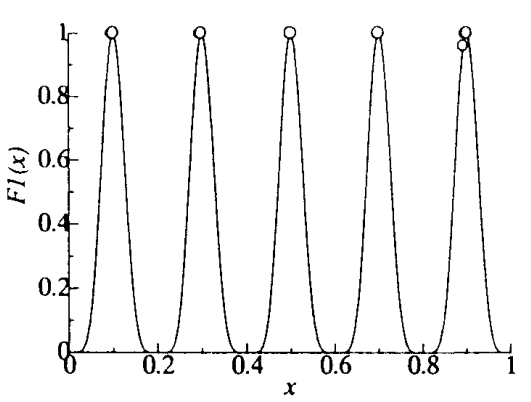

(a)関数 $F 1$ に对する記境練胞

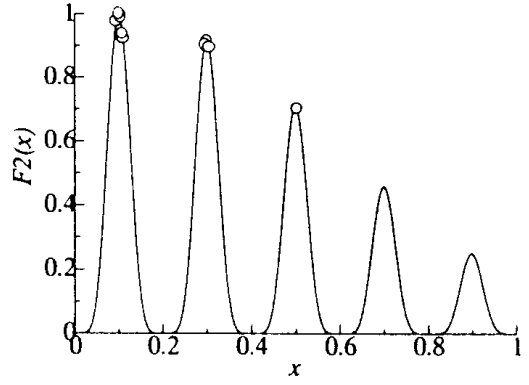

(b)関数 F2に対する記镱緗胞

図-6＼cjkstart改良型 IA により得られた記憶細胞

の個体は1つの最適解付近に収束していることがわか る.また，図-5(a)に示すように，大きさの異なる極大 值を5つ有する関数 $F 2(x)$ に対しては，大部分の個体 が唯一の最適解付近に収束していることがわかる。な お，収束していない個体は，突然变舆の影響を受けた ものと考えられる。それに対して従来のIAを用いる と, 网-4 (b) と図-5(b)に示方ように，耐関数に対して サプレッサー細胞の働きにより1つの局所解に陥るの ではなく幅広い範囲で解の探索を行うため, 複数個の 極大值付近を示す記憶細胞が得られている. 特に関数 $F 2(x)$ に対しては, 最適解はもちろんのこと, やや最適 解より小さな值を持つ極大值をも抽出していることが わかる.しかしながら, 関数 $F 1(x)$ の5つ最適解すべて を求められていないのは，シミュレーションに対して 抗体数が 30 と少なかったことと世代数が小さかった可 能性が考えられる。

このシミュレーションで示されたように, 複数の最 適解を有する関数を目的関数とする最適化問題に対し， 従来のIA では抗体数および世代数に比較的小さい数 を設定するとすべての点を求めることは困難であると 思方れる，そのため，すべての最適解を求めるには抗 体数と世代数をある程度大きな值を取る必要があるが, 対象とする問題によっては, 評価関数の計算に多くの 計算時間を必要とする場合があり，解を得るまでに莫 大な時間を要することになる，そこで，抗体数と世代
数をある程度小さくしたときにも確実に複数の解を得 ることを目的として改良したのが改良型IAである。

改良型 IA の有効性を示すために同様のシミュレー ションを行った。シミュレーションは式(7)および式 (8)で示した関数 $F 1(x)$ および関数 $F 2(x)$ を対象とし, 前節の従来のIA で用いた条件と同じ条件で行った。 改良型 IAにより得られた結果を図一6に示す。

関数 $F 1(x)$ に対して従来のIA では，図-4からもわ かるように最終世代までに5つの最適解のうち3つある いは4つの最適解付近の記憶細胞しか生成できなかっ た.しかし，罒-6(a)に示されているように，同じ条件 下にも関わらず，改良型 IA を用いると5つすべての最 適解付近の記憶細胞が生成されている。 また，大きさ の異なる局所解を複数有する関数 $F 2(x)$ に対しては, 四-6(b)に示すように最適解だけでなく, 従来のIAに 比べると改良型 IA の方がある程度低い局所解まで探 菜していることから，柔軟性をもって多点探索が行わ れていることがわかる。以上のことから，改良型 IA は 従来のIAよりも多様性をもって多点探索が行われて おり, 従来のIAよりも多点探索を行う問題を扱うに は有効であるといえる。

また, 単純 GA とIA の大きな違いの1つであるサプ レッサー細胞の影響を検証するために，本シミュレー ションで得られた多様度の推移を図-7に示す。多様度 [11]とは，産生した抗体の多様性を測定する尺度であ 


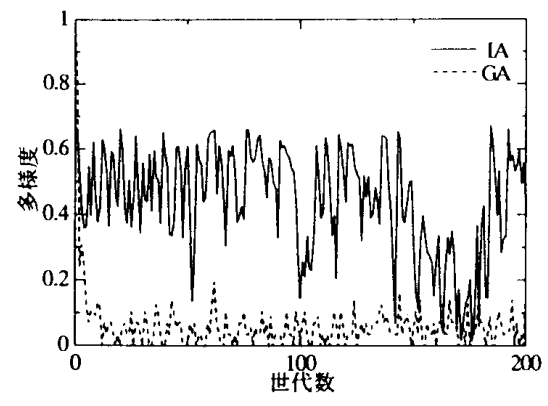

（1）因体数・抗体数 30

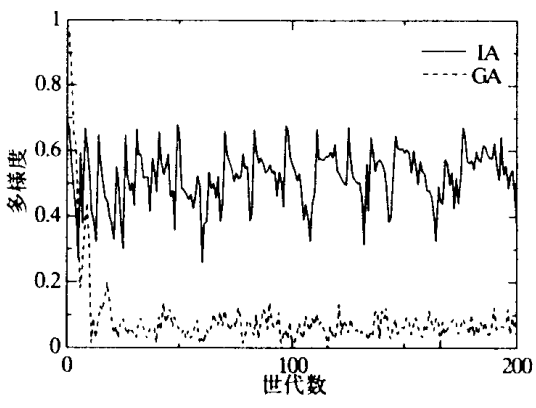

（2）個体数

図-7 単純 GA と改良型 IA の多様度の推移

り，多様度は次の手順で得られる。 $M$ 個の遺伝子をも つ $N$ 個の抗体(個体)により抗体(個体)群が構成され ており，抗体のとりうる記号が $S$ 個存在する。このと き抗体(個体)の遺伝子座 $j$ の情報エントロピー $H_{j}$ (N) は次式で表される。

$$
H_{j}(N)=\sum_{i=1}^{S}\left(-p_{i j} \log p_{i j}\right)
$$

ここで,

$$
p_{i j}=\frac{\text { (遺伝子座 } j \text { に出現した } i \text { 番目の記号の総数) }}{N}
$$

したがって, 抗体(個体)群の多㥞性の平均エントロ ピーH $(N)$ は次式で表され, 抗体(個体)群の多様性を 測定することができる.

$$
H(N)=\frac{1}{M} \sum_{j=1}^{M} H_{j}(N)
$$

ここでは，単純 GA と改良型 IA による結果を比較 した。なお，個体数および抗体数は100個としたときの 結果も示す.個体数および抗体数が30のときと100のと きの両シミュレーションにおいても, 単純 GA では手 法特有の初期収束の早さにより個体のほとんどが早い 世代で収束するために多様性が低くなっている。それ に対して, 改良型 IA ではサプレッサー細胞の働きに より常に新しい抗体を産生することにより多様性を維 持していることがわかる。ここで，抗体数が30のとき に150世代目あたりから180世代目あたりにかけて多様 度が低くなっているのは，ほとんどの解候補を検出し たことにより新しいサプレッサー細胞が産生されなく なり, サプレッサー細胞により消滅される抗体の数が 減少したために，新しく産生される抗体の数が少なく なったためと思われる。この結果からサプレッサー細 胞により多点探索能力が維持されていると考えられる.

\section{4. 耐衝撃設計支援システムへの適用}

ここでは，改良型 IA を構造物の設計支援に適用し

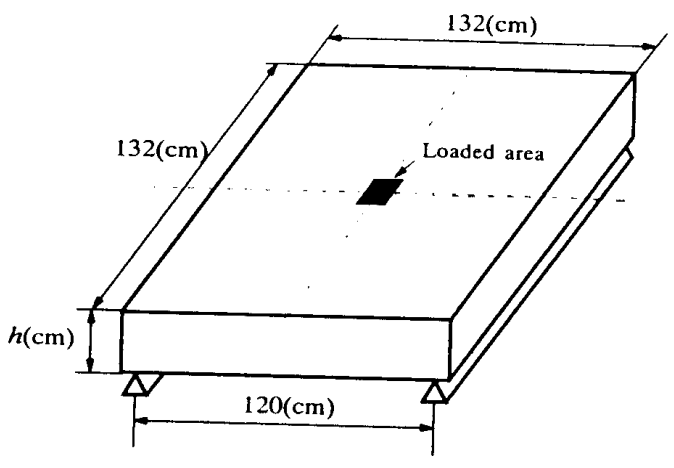

図-8＼cjkstart設計対象 RC 版

た例として， RC 版耐衝撃設計支援システムへの適用 例について示す。

本研究で設計の対象とした RC版を図-8に示す。こ の RC 版は，縦横それぞれ $132 \mathrm{~cm}$ の正方形の複鉄筋 $\mathrm{RC}$ 版で, 厚さは任意に設定可能である。今回設計の対 象としているのは，この RC 版がスパン長 $120 \mathrm{~cm} て ゙ 2$ 辺単純支持され，その中央部に三角形近似された衝撃 荷重が作用した場合を想定している。

衝撃荷重を受ける RC 版の設計では、コンクリート の種類や版厚, 使肘する補強筋の種類, 本数, 太さな ど種々のパラメー夕を効果的に組合せ，耐衝撃性に優 れたものを設計する必要がある。また，このような RC 版の設計では，現場での施工性など評価関数として表 せない項目もあり, 複数の設計案が提示でき，その中 から設計者が施工性や環境条件などを総合的に判断し て設計案を絞ることができれば，より実用的な設計を 行える可能性がある。耐衝撃性の評価としては, 近年 の数值解析手法の発達により, 動的非線形有限要素法 (FEM)による衝撃破壊挙動解析が行えるようになっ たことからその解析結果を用いる。動的で非線形な解 析を行うため計算時間が掛かり，また設計パラメータ も多いことから全ての組合せに対して計算を行い，設 計案を検討することは, 実用上不可能であるため, 改 良型 IAにより設計案の提示を行う。 


\section{1 積層化非線形有限要素解析法 [12]}

衝擊荷重を受ける RC 版の挙動を解析する方法とし て, 本研究では, 積層化非線形有限要素解析を用いて いる。本解析手法は， RC 版を版厚方向に層状に分割 し, 各層に薄版の曲代有限要素法を適用し, 積層化手 法を用いることにより弾塑性解析を可能とした手法で ある。本研究では， $\mathrm{RC}$ 版の対称性を考虑した1/4部分 のみの解析を行う。有限要素解析の解析モデルを図-9 に示す。

\section{$4.2 \mathrm{RC}$ 版の特性のコーディング}

$\mathrm{RC}$ 版の衝撃解析手法を IA に適肘するためには, $\mathrm{RC}$ 版の特性を2進数にコーディングする必要がある。 ここで, RC 版の特性とは構成する要素のことで, 例え ば，鉄筋の種類，本数そして太さやコンクリートの種 類, 厚さなどである。な㧍, 冬パラメー夕要素の要素 数は，2進数でコーディングしているため，できるだけ 2の累乘になるように設定した。2の累乘にならないパ ラメータ要素については, 残りのコードはすべて致死 遺伝子として扱った，RC版の特性のコ一ディングを 表-1に，遺伀子のコーディングの例を网-10に示す。

\section{3 構造設計支援システムの精度の検証}

改良型 IA を用いた構造設計支搤システムの精度を 検証するために，ある制約条件下で RC 版モデルに対 する解析および設計シミュレーションを行った。全通 りの組合せについて RC 版の衝撃破壊挙動解析を行う には，膨大な計算量を必要とし，時間的に困難である。 そこで，版、部と版下部のコンクリートの材料を統一 し, 補強筋の形状である D6とD10を致死遺伀子として 取り扱うことにより組合せ数を減らしてシミュレーシ ヨンし，精度の検証をを行ったままた，配力筋の本数は 主筋の本数の半分とし,版1/4部分に扔ける主筋の本数 の選択範闻は，4本，6本，8本，10本とした。このとき の RC 版モデルのコーディング例を図-11に示す.この ときの組合せは, $110,592(=4 \times 3 \times 6 \times 4 \times 4 \times 6 \times 4 \times 4)$ 通りとなり，時間的にも充分計算可能である。この 110,592通りの組合せに対し，衝撃破壊挙動解析を行 い，その結果を評価值順に並べたものと，改良型IAに よる結果とを比較した，さらに，単純 $\mathrm{GA}[1]$ による結 果との比較も䘕った。精度検証のシミュレーションで は載荷速度を $50 \mathrm{tf} / \mathrm{msec}(490 \mathrm{kN} / \mathrm{msec})$ とし，世代数は 200 中代，抗体数あるいは個体数を30，交文確率を 1.00 , 突然変異率を $1 \%$ として, 次に示す設計問題を設 定した。なお，単純 GAに扔いて選択(淘汰)方式は工 リート保存方式を行ったのちルーレット方式を行う方 法とし, 改良型 IA の各䦨值を $T_{a c 1}=0.50, T_{a c 2}=$

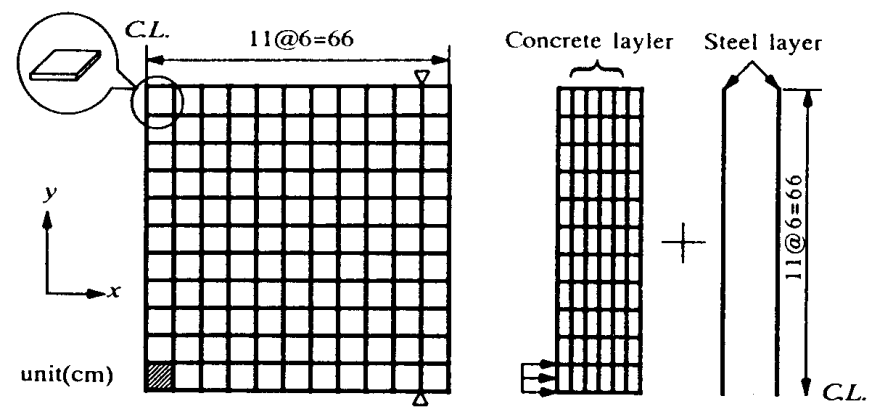

図-9 積層化有限要素モデル

表-1ＲC 版の特性コード一覧表

\begin{tabular}{|c|c|c|}
\hline 要素名 & パラメー夕要素 & $コ-F$ \\
\hline \multirow{4}{*}{ 版串 } & $11.05(\mathrm{~cm})$ & 00 \\
\hline & $11.70(\mathrm{~cm})$ & 01 \\
\hline & $12.35(\mathrm{~cm})$ & 10 \\
\hline & $13.00(\mathrm{~cm})$ & 11 \\
\hline \multirow{3}{*}{ コンクリートの厘類 } & 尊通コンクリート & 00 \\
\hline & 高強度コンクリート & 01 \\
\hline & 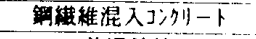 & 10 \\
\hline \multirow{4}{*}{ 補強筋の種類 } & 普通鉄箭 & 00 \\
\hline & 高強度钱筀 & 01 \\
\hline & 連紿織維補強胼(Type.A) & 10 \\
\hline & 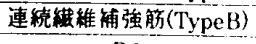 & 11 \\
\hline \multirow{8}{*}{ 蜅強筋の形状 } & D6 & 000 \\
\hline & D 10 & 001 \\
\hline & D13 & 010 \\
\hline & D16 & 011 \\
\hline & D19 & 100 \\
\hline & D22 & 101 \\
\hline & D25 & 110 \\
\hline & D29. & 111 \\
\hline \multirow{8}{*}{$\begin{array}{c}\text { 禣強筋の本数 } \\
(\mathrm{R} C \text { 版の } 1 / 4 \text { 部外) }\end{array}$} & 3(本) & 000 \\
\hline & 4(本) & 001 \\
\hline & 5 (本) & 010 \\
\hline & 6(本) & 011 \\
\hline & $7(4)$ & 100 \\
\hline & $8($ 本 & 101 \\
\hline & 9(本) & 110 \\
\hline & $10($ 本 $)$ & 111 \\
\hline
\end{tabular}

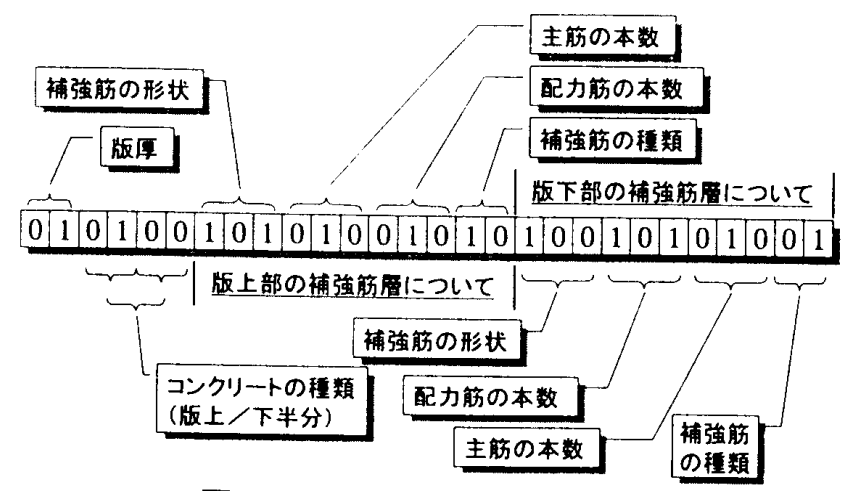

図-10 RC 版のコーディング

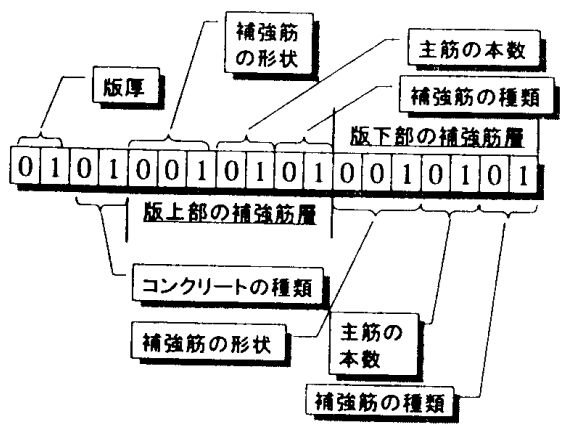

図-11 検証に䏳いた RC 版の特性のコーディング 
$0.50, T_{a c 3}=0.50, T_{c}=0.45 と し$, サプレスパワーを

1.5 とした.

く精度検証のための設計問題＞

【目的関数】

局部変形指数が 0.0020 で破壊する $\mathrm{RC}$ 版を設計

【制約条件】

$\mathrm{RC}$ 版の最大重量：540kgf (5.30kN)

ここで，局部変形指数 [13]とは, FEM 解析により得 られた RC版の変位をもとに計算された值で，破壞時 の曲率を載荷点変位で除した值であり，この值は，破 壊モードとの相関性が高く，局所的な変形が少ないほ ど小さな值となり，破壊時エネルギ一吸収が大きい曲 げ破壊モードに至る指標となる。

構造設計閏題において，組合せ数を減らした全ての 特性の組合せに対して積層化非線形有限要素解析を行 い，その結果得られな最条件に合う10個の RC 版モ デルを表-2に示す。ここで網掛けをしている $\mathrm{RC}$ 版モ デルは改良型 IAにより得られた設計案の出力結果で ある.表-2に示されるように，改良型IAにより最毛条 件に合う1番目の設計案(1)およ゙翻目の設訃案(2)が抽 出された。さらに4番目および7番目に值の良い設計案 导得られている。ここでは尔していないが11番目に良 い設計案も得られた。その設計案は版厚が $12.35 \mathrm{~cm}$ で 局部変形指数が 0.0019996 という十分な精度を持つ解
であり，これにより改良型 IAにより版厚が $11.05 \mathrm{~cm}$, $11.70 \mathrm{~cm} ， 12.35 \mathrm{~cm}$ のそれぞれについて設計案が得ら れ，改良型 IA により複数の解を精度良く，かつ多様な 複数の設計案を提示できると思われる。それに対して 単純 GA により得られた設計案は，表-3に示すように 10世代目には9番目に值の良いRC版モデルを検出し ており，20世代目にはその RC版モデルに収束してい る.その後, 他の新しい RC版を検出することはなかっ た。これは単純 $\mathrm{GA}$ 特有の初期収束により，局所解に 陷ったものと思われる。そこで，突然変異率を5\%とし てシミュレーションを行った。 その結果, 聟然変異率 が1\%のときよりも多様性が保持されるためにやや収 束しにくくなったものの, 表-4に示すように20世代目 には突然変異率が1\%のときよりも良いRC版の設計 案が得られた，結果として改良型 IAにより得られた 結果と比較するとやや精度が落ちるものの，複数解を 求めるために精度の良い解を確実に得るためには 100 世代は必要と思われる改良型IAに対し, 単純 GA で は，20世代程度で良い解を得ることができ，非常に短 時間で良い值を検出できたといえる。

これらの結果から，改良型 IA を用いた構造設計支 援システムを肺いることにより，精度よく設計案を提 亦できると考えられる。それと比較すると単純 GAを 用いな構造設計支援システムの精度は良いとはいえな い。これは複雑な目的関数をもつ問題に対して, 単純

表-2 設計開題に対して解析および改长型IAにより得られた設計案

\begin{tabular}{|c|c|c|c|c|c|c|c|c|c|}
\hline \multirow{2}{*}{ 設計案 } & \multirow{2}{*}{$\begin{array}{l}\text { 版厚 } \\
(\mathrm{cm})\end{array}$} & \multirow{2}{*}{ コンクリートの種類 } & \multicolumn{3}{|c|}{ 版上部の補強筋 } & \multicolumn{3}{|c|}{ 版下部の補強筋 } & \multirow{2}{*}{$\begin{array}{c}\text { 局部変形指数 } \\
\left(10^{-2} / \mathrm{cm}^{2}\right)\end{array}$} \\
\hline & & & 形状 & 主箭本数 & 種類 & 形状 & 主筋本数 & 種類 & \\
\hline (1) & 11.70 & 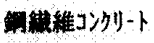 & D22 & 8 本 & FRP 筋 Type B & D16 & 12 本 & FRP 箁 Type B & 0.2000025 \\
\hline (2) & 11.05 & 高強度了加 -1 & D13 & 8 本 & FRP 觔 Type B & D13 & 8 本 & FRP 筇 Type B & 0.2000104 \\
\hline (3) & 12.35 & 耠織維コン夘ート & D22 & 8 本 & FRP 笳 Type B & D16 & 8 本 & FRP 管 Type B & 0.1999868 \\
\hline (4) & 11.70 & 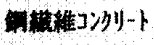 & D16 & 12 本 & FRP 筋 Type B & D16 & 12 本 & FRP Type A & 0.1999843 \\
\hline (5) & 11.05 & 高強度コ夘ート & D13 & 8 本 & FRP 管 Type A & D13 & 8 本 & FRP 筋 Type B & 0.1999835 \\
\hline (6) & 12.35 & 鋼織維コ㱙一ト & D19 & 12 本 & FRP 管 Type B & D16 & 8 本 & FRP 筋 Type A & 0.2000199 \\
\hline (7) & 11.70 & 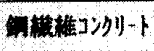 & D13 & 20 本 & FRP Type A & D16 & 12 本 & FRP 觔 Type B & 0.1999782 \\
\hline (8) & 12.35 & 鎆織維コンクリート & D19 & 8 本 & FRP 筋 Type B & D19 & 8 本 & FRP 筋 Type B & 0.1999776 \\
\hline (9) & 11.05 & 高強度コン夘ート & D16 & 16 本 & FRP 管 Type B & D13 & 8 本 & 普通鉄筋 & 0.1999738 \\
\hline (10) & 12.35 & 鋼織維コンクリート & D16 & 20 本 & FRP 㳙 Type B & D13 & 12 本 & FRP 笳 Type B & 0.2000333 \\
\hline
\end{tabular}

注）綱掛けがされているRC版モデルは設計シミュレーションにより得られた設㖶案

表-3 設計問題に対して単純 GAにより得られた設計案(突然変異率1\%)

\begin{tabular}{|c|c|c|c|c|c|c|c|c|c|}
\hline \multirow{2}{*}{ 世代 } & \multirow{2}{*}{$\begin{array}{l}\text { 版厚 } \\
(\mathrm{cm})\end{array}$} & \multirow{2}{*}{ コンクリートの種類 } & \multicolumn{3}{|c|}{ 版上部の補強筋 } & \multicolumn{3}{|c|}{ 版下部の補強筋 } & \multirow{2}{*}{$\begin{array}{c}\text { 局部変形指数 } \\
\left(10^{-2} / \mathrm{cm}^{2}\right)\end{array}$} \\
\hline & & & 形状 & 主筋本数 & 種類 & 形状 & 主筋本数 & 種類 & \\
\hline \multirow{3}{*}{10} & 11.05 & 高強度コ决ート & D16 & 16 本 & FRP 筋 Type B & D13 & 8 本 & 普通鉄筋 & 0.1999738 \\
\hline & 11.05 & 高強度コ㚈ート & D13 & 20 本 & FRP 筋 Type B & D13 & 8 本 & 普通鉄筋 & 0.2015199 \\
\hline & 11.05 & 高強度コンクリート & D13 & 16 本 & 普通鉃能 & D13 & 8 本 & 普通铁筋 & 0.2018071 \\
\hline 20 & 11.05 & 苒強度コンクリー1 & D16 & 16 本 & FRP 筇 Type B & D13 & 8 本 & 曾通铁筋 & 0.1999738 \\
\hline $30 \sim$ & 11.05 & 高強度コシクリート & D16 & 16 本 & FRP 筋 Type B & D13 & 8 本 & 普通鉄筋 & 0.1999738 \\
\hline
\end{tabular}


表-4 設計開題に対して単純 GAにより得られた設計案(突然変異率5\%)

\begin{tabular}{|c|c|c|c|c|c|c|c|c|c|}
\hline \multirow{2}{*}{ 世代 } & \multirow{2}{*}{$\begin{array}{l}\text { 版厚 } \\
(\mathrm{cm})\end{array}$} & \multirow{2}{*}{ コンクリートの種類 } & \multicolumn{3}{|c|}{ 版上部の補強筋 } & \multicolumn{3}{|c|}{ 版下部の補強箭 } & \multirow{2}{*}{$\begin{array}{c}\text { 局部変形指数 } \\
\left(10^{-2} / \mathrm{cm}^{2}\right)\end{array}$} \\
\hline & & & 形状 & 主筋本数 & 種類 & 形状 & 主筋本数 & 種類 & \\
\hline \multirow{2}{*}{10} & 11.70 & 制緘維コンクリート & D13 & 12 本 & FRP 筋 Type B & D13 & 16 本 & FRP 筋 Type B & 0.1999266 \\
\hline & 11.70 & 鋼織維コンクリート & D13 & 16 本 & FRP 筋 Type A & D16 & 12 本 & FRP 筋 Type B & 0.2000815 \\
\hline 20 & 11.70 & 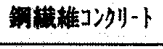 & D13 & 20 本 & FRP 筋 Type A & D16 & 12 本 & FRP 能 Type B & 0.1999782 \\
\hline $30 \sim$ & 11.70 & 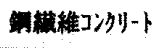 & D13 & 20 本 & FRP 筋 Type A & D16 & 12 本 & FRP 飭 Type B & 0.1999782 \\
\hline
\end{tabular}

GA では手法特有の初期収束によりある程度評洒值の 高い事象を検出するとその事象に収束してしまい，そ の後は広範囲にわたる検索はほとんど突然変異に頼っ てしまうことが原因として考えられる。これに対して 改良型 IA では，ある程度収束した評洒值の高い事象 を解候補として記憶細胞に記憶させ，新たに検索を開 始する。このときサプレッサー細胞の㗢きによりすで に検出した解候補以外の事象を検索するため，より確 実に広範囲にわたる検索が行える。そのため改良型 IA の方がより精度がよく，より多様性に富んだ複数の設 計案を提示できるものと考えられる。

\section{4 設計シミュレーション}

一般的に， RC 版は衝撃荷重下で押し拔きせん断破 壞よりも曲け破壊モードで破壊した方が望ましいと考 えられている。そこで，本構造設計支援システムでは， $\mathrm{RC}$ 版の耐衝撃性評価指標として瓦部的な变形状態を 評価する向部変形指数と RC 版の耐荷性を部佻する破 壊時衝撃数を用いる。この2つの指標を用いて, 以下に 示すような耐衝撃性評価関数を月いる 114$]$.

$$
\text { 耐衝撃性評価関数 }=\frac{\text { 破壊時衝撃何重 }}{\text { 部変形指数 }}
$$

すなわち，破壊時衝撃侕重は大きいもの程良好で， 局部变形指数の値は，曲げ破壞に近いものほど小さく なる。そのため，耐衝撃性評偳関数の值は大きいもの ほど耐衝撃性に優れていることを表す。

\section{$<$ 設計問題 $>$}

\section{【目的関数】}

耐衝撃性の良い RC 版を設計

耐衝撃性評価関数(破壊時衝撃荷重を局部変形指数 で除した值)が大きいものを設計.

【制約条件】

$\mathrm{RC}$ 版の最大重量 : $1.0 \mathrm{tf}(9.80 \mathrm{kN})$

$\mathrm{RC}$ 版に㨂入される補強筋の最大量 (体積)：

(1) $2.5 \times 10^{3} \mathrm{~cm}^{3}$, (2) $1.0 \times 10^{4} \mathrm{~cm}^{3}$, (3) $3.0 \times 10^{4} \mathrm{~cm}^{3}$

なお、ここではコストを考慮していないため，コン クリートの材料の中で極めて強度が高い高強度コンク リートは考慮しなかった。 また, 世代数は150世:代, 抗 体数を 30 , 交义確率を 1.00 , 突然变異摔を $1 \%$ とした。
ここでは, 載荷速度を $25 \mathrm{tf} / \mathrm{msec}(245 \mathrm{kN} / \mathrm{msec}), 50$ $\mathrm{tf} / \mathrm{msec}(490 \mathrm{kN} / \mathrm{msec}), 75 \mathrm{tf} / \mathrm{msec}(735 \mathrm{kN} / \mathrm{msec})$ と して改良型IAにより設計を行った。各制約条件下に おいて得られた複数の設計案のうち，耐衝撃性に優れ た RC 版の中から代表的な設計案を図-12〜図-15に示 す。得られた全ての設計案では，版上部よりも版下部 の補強筋が多く挿入された。一般的には，一方から荷 重を受けるコンクリート構造物はその反対側の面に大 きく引張忍力がかかるため，ロックシェッドのような $\mathrm{RC}$ 版では版上:部よりも版下部における補強筋を多く 洀入した方が良いとされており，目的関数である耐衝 撃性の評価が表れたものと考えられる。また，各条件 下において多種多様な設計案が得られており，補強筋 の材料を変更することにより補強筋の配置が变わるこ とが顕著に表れていると思われ，改良型IAにより複 数の有効な設部案が提示できたといえる.

\section{5. 結論}

本研究では, 最適構造設計閏題に改良型 IA 適用 することを考之，まず始めに，IAの改良を行い，より 確尖に複数の多椂性を持った解が探索できるようにし た。次に, 積層化非線形有限要素解析法を明いて衝撃 荷重を受ける鉄筋コンクリート (RC) 版の設計シミュ レーションを行い, 提示された設計案の妥当性の評価 および改良型 IA と単純 GA の探索能力の評価を行っ た．本研究で得られた結果を以下に示す。

(1) IA は，サプレッサー細胞により多样性を保ち, 探索 範阱を拡げることができるため, 単純 GA よりも精 度の良い解を得ることができることが確認された。

(2) IA では, 最適解が複数存在するときには複数の最 適解を抽出することができ，さらに值の異なる局所 解が複数侗存在する関数に対しても，ある程度大き い值を持つ局所解を検出することができた。また， 改良型IA を用いると, 従来のIAよりも確帮に多く の複数の最適解, あるいは局所解を検出することが できた。

(3)改䬶型IA を用いることにより，高い精度をもって $\mathrm{RC}$ 版の耐衝撃設計を行え，複数の異なる設計案を 提示できることが確認できた。しかしながら，得ら 


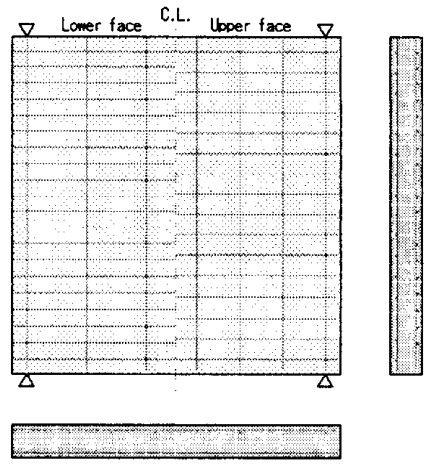

(1) 設計案 1
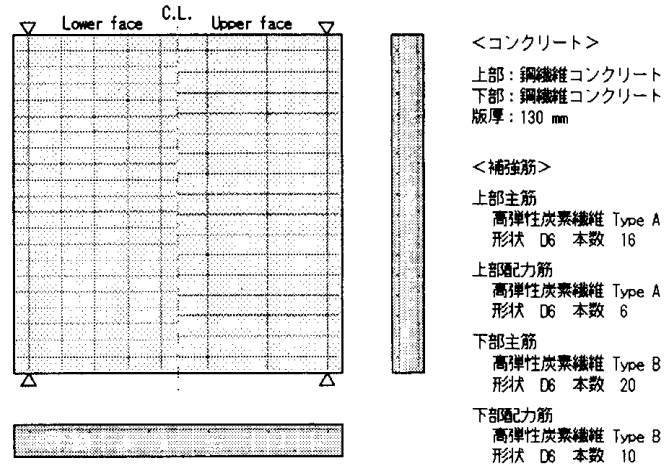

(2) 設計案 2

図-12 得られた設計案

（補強筋量 $2.5 \times 10^{3} \mathrm{~cm}^{3}$ 以下, 載荷速度 $245 \mathrm{kN} / \mathrm{msec}$ )
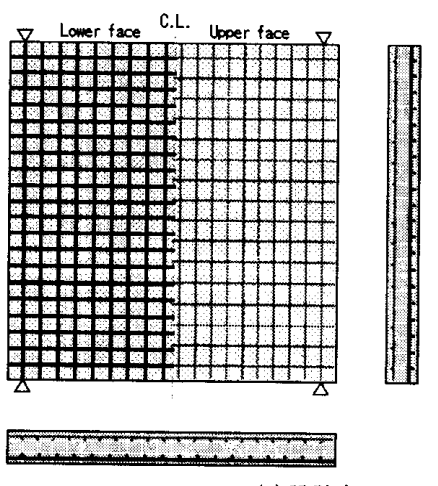

(1) 設計案 1
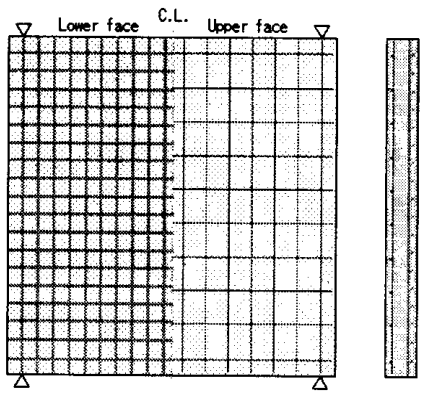

〈コンクリート〉

上部: 䚀䧴コンクリー

版原 : $130 \mathrm{~mm}$

<捕弹筇〉

上部主筋

形犾 06 本数

上部究的第

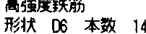

下部主筋

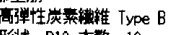

形状 013 本 18

下部改施

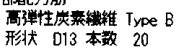

(2) 設計案 2

図-14 得られた設計案

（補強筋量 $1.0 \times 10^{4} \mathrm{~cm}^{3}$ 以下，載荷速度 $735 \mathrm{kN} / \mathrm{msec）}$
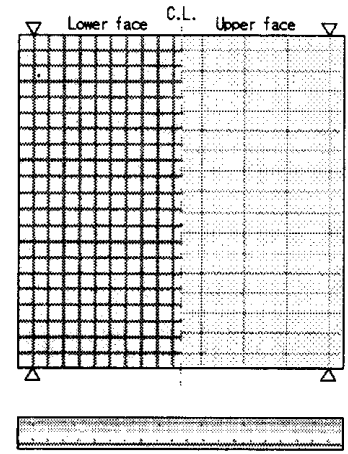

(1) 設計案 1

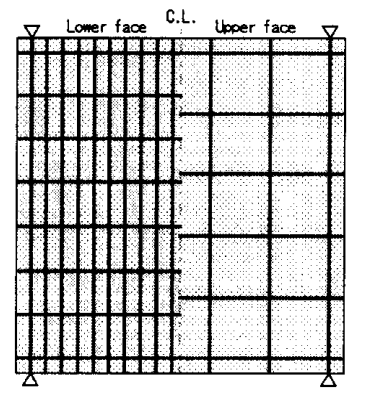

(2) 設計案 2

図-13 得られた設計案

（補強筋量 $1.0 \times 10^{4} \mathrm{~cm}^{3}$ 以下，載荷速度 $245 \mathrm{kN} / \mathrm{msec）}$

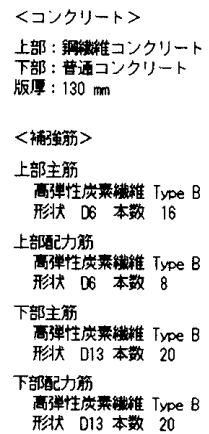

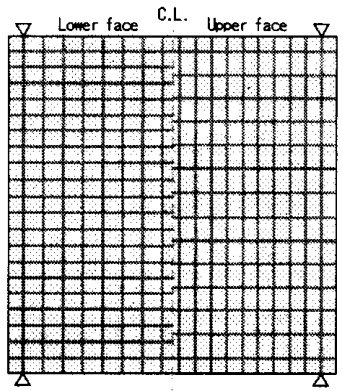

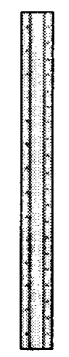

上部 : 船維鹤コンクリート

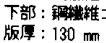

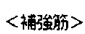

上部主筋

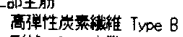

形行 013 本数 14

上部积力第

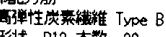
下部主的

下部主筇

形米 013 本效 20

下部通动第

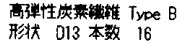

(1) 設計案 1

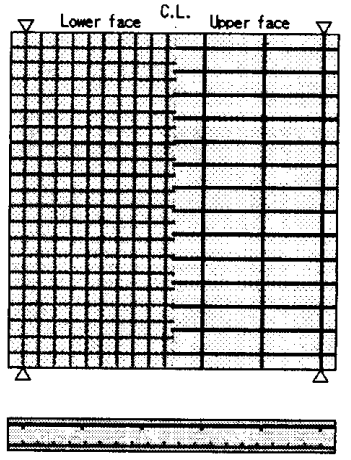

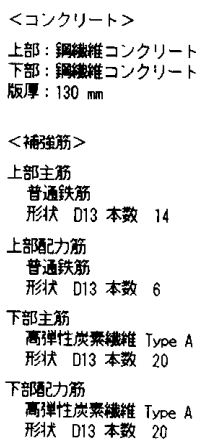

(2) 設計案 2

図-15 得られた設計案

(補強筋量 $3.0 \times 10^{4} \mathrm{~cm}^{3}$ 以下, 載荷速度 $735 \mathrm{kN} / \mathrm{msec}$ ) 
れた複数の設計案の中から提示する案を選択する方 法が末だ確立しておらず，今後，検討する必要があ る.

(4)単純 GA 用いた設計支援システムでは，単純 GA 特有の初期収束により非常に短時間である程度精度 の良い設計案が提示できることが確認された。した がって, 早急に設計案を必要とする場合や単に耐衝 撃性のみを考虑する場合には，単純 GA は有効であ る.

(5)実際の最適構造設計問題では，多くの要因を含んだ 複数の目的関数が存在し，さらには環境条件や景観， あるいは製作・施工条件等の数值で表すことのでき ない項目も考慮しなければならないため，設計者の 意図を反映できるように設計を行うには複数個の設 計案を提示する必要がある。したがって, 改良型 IA は, 単純 GA や従来のIA と比較すると構造設計問 題に対して非常に有効であると思われる。

\section{参考 文 献}

[1]荻原将人：ニューロ・ファジィ・遺伝的アルゴリズム, 産業図書, 1994.

[2]石田良平, 村瀬治比古, 小山修平：遺伝的アルゴリズム の基礎と応用，森北出版株式会社，1997.

[3]千々岩浩巳，三原徹治，太田俊昭：GAによる鋼管杭基 碟構造の最適配置決定法に関する研究, 土木学会論文 集, No.549/ I -37, pp.97-105, 1996.10

[4]D.E. Goldberg: Genetic Algorithms in Search, Optimization, and Machine Leaning, AddisonWesley, 1989.

[5]坂和正敏：遺伝的アルゴリズム，朝倉書店, 1995.

[6]市川, 石井：遺伝子分布評価に基づく遺伝的アルゴリズ
么の多様性維持：計測自動制御学会論文集, Vol.30, No.10, pp.1242-1250, 1994.

[7]森, 吉田, 喜多, 西川：遺伝的アルゴリズムにおける熱 力学的選択ルールの提案, システム制御情報学会論文 誌, Vol.9, No.2, pp.82-90, 1996.

[8]北野宏明：遺伝的アルゴリズム2, 産業図書, 1995 .

[9]J.D Farmer, N.H. Packard and A. S. Perelson: The Immune System, Adaptation, and Machine Learning, Physica 22D, pp.187-204, 1986.

[10]和田健之介, 田中伸一, 和田桂子：進化システム論 遺 伝的アルゴリズムの基礎 (5), Computer Today, 51, No.9, pp.82-87, 1992.

[11]森一之, 筑山 誠, 福田豊生：免疫アルゴリズムによる 多峰性関数最適化, 電気学会論文誌, C117, No.5, pp. 593-597, 1997.

[12] Miyamoto, A., King, W. M., Fujii, M. : Nonlinear dynamic analysis of Reinforced Concrete Slabs under impulsive Loads ACI Structural Journal, Vol. 88, No.4, pp.411-419, 1991.

[13] 宮本文穂, 石橋照久, 三戸雅文 : コンクリート版構造の 耐衝撃性評価に関する研究, 構造工学論文集, Vol.40 A, pp.1605-1618, 1994.

[14]江本久雄, 中村秀明, 宮本文穂：GAによる RC 版酎衝 擊設計支援システムの開発に関する研究, 構造工学論 文集, Vol.45A, pp.453 464, 1999.

(1999年2月25日 受 付) (1999年8月23日 再受付)

[問い合わせ先］

₹755-8611

山口県宇部市常盤台2-16-1

山口大学工学部知能情報システム工学科

中村秀明

TEL \& FAX : 0836-35-9484

E-mail : nakamura @ design.csse.yamaguchi-u.ac.jp

\section{著 者 紹 介}

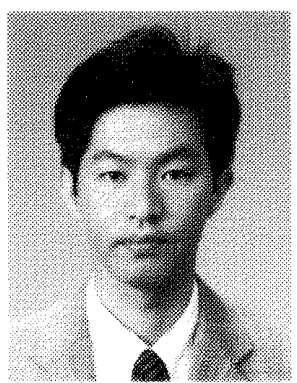

中村 秀明 (なかむらひであき)

山口大学工学部知能情報システム工学科 1986年 山1口大学大学院工学研究科修 士課程土木工学専攻修了. 同年 (侏マツダ 入社. 1988年3月 山口大学工学部土木工 学科助手。1996年7月 同学部知能情報シ ステム工学科助手。1998年5月同助教授, 現在に至る。博士(工学)。主として, Bridge Management System の開発, 遺 伝的アルゴリズムや免疫アルゴリズムの 設計問題への応用に関する研究に従事。 日本ファジィ学会, 上学会, 日本部算工 学会, ACI どの会員.

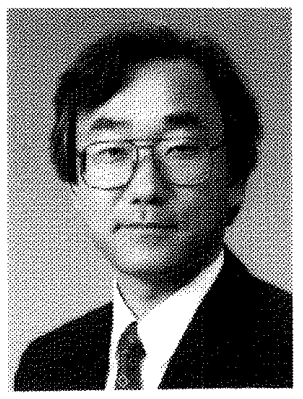

宮本 文穂 (みやもとあやほ)

山口大学工学部知能情報システム工学科 1975年 神户大学大学院工学研究科修 士課程土木工学専攻修了. 同年 同大学工 学部土木工学科助手. その後講師を経て, 1988年 同助教授. 1995年 山口大学工学 部知能情報システム工学科教授, 現在に 至る. 工博. コンクリート橋診断ニュー ロ・ファジィエキスパートシステムの開 発, Bridge Management System $の$ 開発 等，橋梁維持管理のシステム化に関する

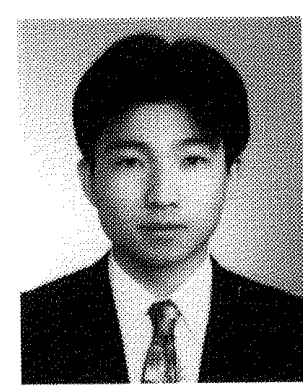

松本 剛(まっもとつょし)

NTT 西日本広島支店法人営業本部 ソリューション部門

1996年 山口大学工学部知能情報シス テム工学科卒. 1998年山口大学大学院理 工学研究科博士前期課程知能情報システ ム工学尃攻修了. 同年 NTTに入社し, 現在に至る。遗伝的アルゴリズム, 免没ア ルゴリズム等のシステム最適化手法に興 味を持つ。現在, NTT 西日本において， 企業の基幹業務の最適化㧧よU゙インフラ 整備に関するソリューション事業に従事。 


\section{Application of the Improved Immune Algorithm to a Structural Design Support System}

by

\section{Hideaki NAKAMURA, Ayaho MIYAMOTO and Tsuyoshi MATSUMOTO}

Abstract :

The Genetic Algorithms (GAs) based on multi-point search method and crossover operation are one of the useful search procedures for combinatorial optimization problems and also applied to many kinds of practical optimization. However, in general, the GAs have a tendency to go down rapidly of the diversity of population in the process of searching. In order to improve this drawback, some researchers have proposed new algorithms for maintaining the diversity of population.

On the other hand, the Immune Algorithms (IAs) are optimization techniques which imitate the immune systems in an organism. The IAs are able to obtain plural semi-optimum solution with maintaining the diversity of population compared with the GAs. In this study, in order to consider the application to optimal design problems in structures, the improvement of convergent and the maintenance of the diversity of population are attempted. Furthermore, improved IA is applied to the impact resistance design problem. It is found that application of improved IA can be used as effective method of structural optimization design base on several simulation results.

Keywords : Genetic Algorithm(GA), Immune Algorithm(IA), Optimum Design, Diversity

\section{Contact Address : Hideaki NAKAMURA}

Computer Science and Systems Engineering, Yamaguchi University

2-16-1, Tokiwadai, Ube, Yamaguchi, 755-8611, Japan

TEL : 0836-35-9484

FAX : 0836-35-9484

E-mail : nakamura@ design.csse.yamaguchi-u.ac.jp 